\title{
Research on the Development of Materials Major in Applied Undergraduate Colleges and Universities
}

\author{
Rui TANG ${ }^{1, a}$ \\ ${ }^{1}$ School of Mechanical Engineering, Panzhihua University, Panzhihua,China, 617000 \\ a904200315@qq.com
}

Keywords: Transformation development; Double-skilled type; The teaching reform

\begin{abstract}
Based on the local ordinary undergraduate course colleges and universities of technical transformation to the application development as the background, from the "double-skilled type " teachers construction and practice teaching system reform, improve students' innovation ability ,two aspects has carried on the thinking and research, put forward the development of materials engineering construction ideas and reform measures.
\end{abstract}

\section{Introduction}

New materials, information technology and new energy are the three pillar industries of national economic development in the 21st century [1].Hundreds of colleges and universities across the country had been opened by the materials science and engineering as the core material or related major, training mode and professional construction ideas are mostly in accordance with the "thick foundation, wide professional, strong ability and high quality" and the principle of the standard implementation. In today's society is in a critical period of development, transformation and industrial structure adjustment of local undergraduate college at the university of technical transformation to the application development process should be adjusted in the specialty construction, reform talents training mode, to cultivate has strong practical application ability and innovation ability of applied talents as the goal, to strengthen the " double-skilled type " teachers team construction as the way, trying to explore materials specialty construction of new ideas, new initiatives, constantly adapt to the needs of the development of local economic and social undertakings.

\section{Construct the "Double-Skilled Type" Teachers Team, and Adapt to the Development Requirements of the Discipline}

Undergraduate colleges and universities is aimed at the cultivation of advanced engineering technology application talents, and constantly improves the theoretical teaching and practical teaching system. The key is to build a high level "double teacher double energy" teaching staff. "Double master" teachers have both solid professional theoretical knowledge and practical skills in relevant industries. "double-skilled type" refers to teachers who have both professional theoretical teaching skills and professional practical skills, and have professional qualification certificates and practical skill certificates.

\section{Focus on the Construction of the Four-in-one "Double-Skilled Type" Teacher Training System}

As local ordinary undergraduate course colleges and universities gradually to the application of technical transformation of university development, the construction of disciplines geared to the needs of society, more and more close to the practice, it puts forward the construction of teachers' team higher update requirements [2].Four one of the "double double-skilled type " teachers training

Fund project: innovation team of sichuan education department "titanium metal smelting and its alloy preparation and development and application" (project no. : 15DT0042) 
system arises at the historic moment, which includes online learning platform, academic promotion platform, a platform to improve and professional development skills, four platforms is mutual promotion and relatively independent. Online learning platform is an online lifelong learning of theoretical knowledge and teaching skills using advanced modern education technology and network platform. The academic promotion platform refers to the improvement of academic level and scientific research ability by providing teachers with the opportunity to improve their academic qualifications, study and further education at home and abroad. The skills enhancement platform refers to the training and skills upgrading of teachers through the training, school-enterprise and school cooperation in enterprises and institutions. Platform is used to improve young teachers' professional development and external part-time teachers' teaching ability and the academic level, the basic teaching of training teachers, such as the teaching methods and teaching art, students' psychological cognition and evaluation and feedback, etc. The online learning platform is the foundation, the academic promotion platform is the means, the skill strengthening platform is the key, the professional development platform is the guarantee, and the four people are both self-formed and mutually reinforcing. Ability through teaching evaluation, professional title assessment, performance appraisal, rewards and punishments, salary incentive and value realization of the reform, the construction of a high quality, strong ability of high levels of double type teachers, promoting local features high level university construction and development.

\section{Constantly Improve the Incentive System of "Double-Skilled Type" Teachers}

Can in the " double-skilled type " teachers construction process, to build a set of reasonable and effective teacher incentive mechanism, cultivating the lead teachers to high levels of " double-skilled type " development, through establishing and perfecting policy treatment, evaluation and appropriate emotional three incentive mechanism to guide and encourage the development of teachers and grow up. Treatment of policy incentives are setting up "can double-skilled type " teachers actively participate in school teaching research and social service system and policy, and to young teachers a line worker tilt policy treatment, can stimulate the teachers to learn and work in a large extent enthusiasm, help and promote young teachers constantly improve and progress; The evaluation and evaluation motivation refers to the realization of teachers' self-worth, enhancing teachers' sense of identity and belonging to the school. Through assessment and evaluation, the author finds out the problems existing in the development process, and helps teachers to find the gap, make clear efforts and improve the direction; Appropriate emotional incentive is to point to by regulating and guiding teacher's value orientation and behavior, to improve the working ability and teaching level, pay attention to the problems encountered in the development of teachers' transformation and difficulties, help them to overcome and solve properly, formed to promote teachers' development and progress of cohesion and centripetal force, arouse their enthusiasm and initiative in work.

\section{Strengthen Practical Teaching and Improve Students' Ability to Apply Innovation}

In the transformation and development of local colleges and universities, it is very important to reform students' teaching practice. Innovative talent training is the key to the combination of theory and application, namely the combination of theoretical knowledge and practical skills, innovation spirit and practice ability, combining with culture has a solid professional knowledge and skilled professional skills, to cultivate senior engineering personnel for production line for the final training target, strengthen the practice teaching link, to improve students' practical application of the comprehensive ability and engineering quality.

\section{Strengthen the Teaching Concept with the Cultivation of Practical Ability as the Core}

Practical teaching is an important link in the cultivation of innovative talents for materials. [3].The main task of practical teaching is to consolidate basic theory and cultivate practical application ability of engineering. The materials are specialized in the fields of metals, inorganic nonmetals and polymer materials, covering a wide range of fields and interpenetrating and intersecting disciplines. 
Therefore, in the professional curriculum and teaching arrangement, should pay attention to the discipline of engineering background, insist on experiment teaching combined with the actual industrial production, adhere to the engineering basic training combined with innovation ability. In the process of discipline construction, combining with the reform of engineering education professional certification and excellent engineer training and development needs, take full advantage of innovation laboratory personnel and equipment resources, attracting outstanding students into scientific research team, to participate in research projects, broaden the vision of scientific research and innovation ability, better play to the role of the innovation laboratory.

\section{Vigorously Build a Scientific Practice Practical Teaching System}

Scientific and effective practice teaching system is the key to improve the quality of applied talents training, according to the demands of the development of application technology college transition, according to the actual production practice and technical process, build a predominantly technical skill training practice teaching system, through the establishment of diverse, hierarchical practice teaching platform, and engineering practice ability training for college students' innovative application requirements [4].Traditional practice teaching of the course is mainly based on cognitive and validation experiments, the lack of effective integration, and relatively independent between each experiment course and practice, students' cognitive practice, production practice and graduation practice is not close, the practice innovation ability is hard to get a good promotion. In accordance with the "thick foundation, strong ability and high quality, heavy application of" the practice of applied talents training principle, reconstruct the new practice teaching course system, by setting up a foundation platform experiment, professional foundation platform and professional design practice three links such as platform, set up open laboratories, pilot comprehensive interdisciplinary course experiment, inspire students' innovation consciousness and improve students' practical ability, to promote engineering education accreditation and excellent engineer training to obtain actual effect. .The training of three practical teaching platform links can effectively cultivate students' strong professional application ability, independent practical operation ability and innovative analysis and design ability.

\section{Change Assessment Methods and Cultivate Students' Comprehensive Application Ability.}

Test or inspection as a measure of the last link of the teaching quality, directly testing the teaching effect, the practice teaching link, the most by experiment report, internship summary or submit a paper form to the effect of testing students internship practice, lack of dynamic evaluation of practice process, and the measure of the students' cognitive experience and skills upgrading [5].At present, the evaluation system of practice teaching in colleges and universities is not perfect, because it is not enough to establish a relatively perfect assessment system. Second, the evaluation of practical teaching has a certain degree of subjective randomness, which is difficult to quantify. The third is the practice teaching assessment of the main reference practice activity summary, ignores the student's actual harvest and the concrete performance. Therefore, in the practice teaching evaluation standard, should highlight the students innovation ability analysis to solve the problem and application of appraisal, the "students' evaluation of teaching" and "teacher learning" two links are closely combined, formation evaluation in the interactive teaching mode, and promote the teachers and students work together to improve the practice teaching, to do the scientific rationality of evaluation.

\section{Conclusion}

In local normal colleges and universities to the development of transformation, the application technology university majoring in material reform the way to the teacher and the student two fundamental elements, one is by building a high efficient, practical and stable high levels of " double-skilled type" teachers, according to four one of the teacher training system, all-round improve teachers' comprehensive quality and ability; The second is to build practical teaching system, to satisfy the needs of the personnel training mode to train "with strong innovation 
consciousness and strong practice ability [6]" the advanced engineering technology applied talents as the goal, to promote local economic and social development and progress.

Analysis on the Development of Materials in the Background of Transformation and Development of Applied Undergraduate Universities

\section{References}

[1] Zhang Xiaobo. The Cultivation of Practical Talents for Application-oriented Undergraduate Materials Oriented to Industrial Transformation [J]. China metallurgy education, 2012 (5) : 47-50.

[2] Glinhai. Research On the Training and Incentive Mechanism of "Double Teacher" Teachers in the Transformation of Local Universities [J]. Journal of shijiazhuang university,2015 (6) : 96-100.

[3] Liu Tianmo. Discussion on the Cultivation of Innovative Practical Ability of Materials Students [J]. Laboratory research and exploration, 2011 (7) : 88-90.

[4] Wang Fang. Research on the Reform of Material Professional Practice Teaching for Compound Talent Training $[\mathrm{J}]$. Journal of southwest normal university (natural science edition), 2014(2)156-162.

[5] Miliwei. A Discussion on the Construction of a Curriculum System for Materials Science and Engineering [J]. Guangzhou chemical industry, 2015(10) : 164-165.

[6] Miliwei. Research and Practice of Innovative Talent Training System in Materials Discipline [J]. Science and technology innovation guide, 2015(4) : 170. 